\title{
SOCIAL ENGAGEMENT AND MULTICULTURALISM IN LOUIS ADAMIC'S LITERARY JOURNALISM AND DOCUMENTARY PROSE
}

Leonora FLIS

COBISS 1.01

\section{ABSTRACT \\ Social Engagement and Multiculturalism in Louis Adamic's Literary Journalism and Documentary Prose}

The article focuses on those texts by Louis Adamic that, by employing the principles of literary journalism, create an authentic discourse (which is simultaneously subjective and documentary) for the description of both current and past events, and successfully place Adamic alongside more recognizable names in the field of literary journalism. The article also explains the characteristics of literary journalism and identifies the traits of this genre in those of Adamic's works that involve a multiculturalist criticism of the homogenizing impact of dominant cultures and reveal a powerful social agenda (Dynamite, Laughing in the Jungle, My America, The Native's Return, and A Nation of Nations).

KEY WORDS: Louis Adamic, literary journalism, multiculturalism, social engagement, migration

\section{IZVLEČEK}

Družbeni angažma in multikulturalizem v literarnem novinarstvu in dokumentarni prozi Louisa Adamiča

Članek se osredotoča na besedila Louisa Adamiča, ki s pomočjo pristopov literarnega novinarstva oblikujejo avtentični, hkratno subjektivni in zgodovinsko preverljivi diskurz opisovanja tako aktualnih kot preteklih dogodkov in Adamiča uspešno postavljajo ob bok širše prepoznavnim imenom literarnega novinarstva. Članek pojasni lastnosti literarnega žurnalizma ter identificira poteze tega žanra v tistih Adamičevih besedilih, ki še zlasti jasno izražajo multikulturalistično kritiko homogenizirajočih vplivov prevladujočih kultur in izkazujejo močno socialno agendo (Dinamit, Smeh v džungli, Moja Amerika, Vrnitev v rodni kraj in Narod narodov).

KLJUČNE BESEDE: Louis Adamič, literarno novinarstvo, multikulturalizem, družbeni angažma, migracija

PhD in Literary Studies, Adjunct Associate Professor at the University of Nova Gorica and Assistant Professor and English Lecturer at the University of Ljubljana; leonora.flis@fdv.uni-lj.si 


\section{INTRODUCTION}

As a keen social observer and a relentless fighter for the improvement of the living standards of the working class and the immigrant population in the United States and beyond, Louis Adamic never lacked for worthwhile material to reflect upon. It made its way into his numerous articles and books which clearly define him as one of the most successful and respected journalists and prose writers among Slovene immigrants in the U.S. to date. Adamic, who emigrated to the U.S. in 1912 at the age of 14 , had a distinct desire to merge with the American world, yet never at the expense of losing his Slovenian identity and roots. In this article, I show how Adamic, in his longform journalism that found its most accomplished formal and semantic expression in his books, matches the quality of writers of his time as well as those who came before him who are usually labelled "literary journalists". He can undoubtedly be considered as one of the key representatives of this genre, even though he is not often quoted among his literary-journalistic contemporaries (e.g. Edmund Wilson, James Agee, Martha Gellhorn, and H. L. Mencken).

I will explore Adamic's longform journalism, which spilled into his books (which often function as generic hybrids). However, we can still clearly identify features of documentary prose that carries within it the essential qualities of literary reportage.' In the 1930s, Adamic, alongside other prominent writers and reporters of his era, started creating texts focusing on the social conditions of the world they lived in, on the "thoughts and aspirations of ordinary people", as Richard H. Pells notes in Radical Visions and American Dreams: Culture and Social Thought in the Depression Years (1998). Those endeavours, in Pells' words, were in essence a quest for the social fact, a quest done through reportage that was more appropriate for capturing the conditions of the times than fiction, which "appeared powerless to cope with reality" (Pells 1998: 195). Michael Denning, in his book The Cultural Front: Laboring of American Culture in the Twentieth Century (1996), observes that the history of 'writers on the left' has also been a history of literary journalism, and notes the importance of Adamic's work on race and ethnicity, yet he, similarly to Pells, doesn't sufficiently explain how "literarized" reportage as a genre (in Adamic's case and with other writers he mentions - Agee, Wilson, and Steinbeck, to name a few), can be used, precisely due to its specific nature, as a powerful tool to illustrate the pressing issues of the times. My article will explore the ways in which Adamic used the principles of literary journalism in his reportage and thus made it more alive, more tangible, and more efficient in expressing his socially-charged agenda and in creating the foundations of the concept of multiculturalism.

1 I use the terms literary journalism and literary reportage synonymously. 


\section{LITERARY JOURNALISM (AND DOCUMENTARY PROSE) AS A GENRE AND ADAMIC'S INTRODUCTION TO IT}

As Norman Sims points out in his book The Literary Journalists (1984), literary journalists report on "the lives of people at work, in love, going about the normal rounds of life and confirm that the crucial moments of everyday life contain great drama and substance" (Sims 1984: 3). He goes on to explain that literary journalists "rather than hanging around the edges of powerful institutions, attempt to penetrate the cultures that make institutions work" (ibid). Indeed, literary journalists follow their own rules; they call for the author's complete immersion in the subject matter, or in the life of the subject(s) they are writing about, moreover, the voice of the writer has to surface so it becomes recognizable and his authority must show through. In essence, texts of literary journalism ${ }^{2}$ read like proper stories, like fiction, except that it must all be true. A well-crafted composition, specific stylistic features and a careful use of language are usually noticeably detectable in a piece of literary journalism. Literary journalists and documentary novelists alike (who basically just resort to booklength journalism) ${ }^{3}$ want to move beyond the conventions of traditional journalism or conventional reportage. They both consciously use techniques of fiction in order to create an element of drama or storytelling. Such literary techniques include irony, rhythm, foreshadowing, characterization, plot, dialogue, imagery, metaphor, satire, interior monologues, even stream-of-consciousness. These principles of literary journalism have been in use for over a hundred years, and many writers whose works are now regarded as classics wrote nonfiction works with a distinct literary flair - for example Charles Dickens, Jack London, George Orwell, Stephen Crane, Mark Twain, John Steinbeck, and John Hersey, to name a few.

Nevertheless, it was Tom Wolfe, the proverbial father of New Journalism and cultural icon in the 1960s and the 1970s, who anthologized a group of writers under the rubric "New Journalism"4 and identified them as "rivals to the best novelists of their time" (Flis 2010: 15, 16). In Sims' words: "Literary journalism has developed its styles

2 We should note that there is no uniform terminology with respect to literary journalism; narrative journalism, discursive journalism, intimate journalism, subjective journalism, longform journalism, literary reportage, and simply creative nonfiction have been used to describe texts that could also be considered examples of literary journalism.

3 In the American literary-journalistic sphere, we observe how literary (or subjective) journalism often spills into longer narratives, specifically into documentary novels that constantly oscillate between historical novels, crime narratives, (auto)biographies, travelogues, and political commentaries on the one hand, and a purer form of (literarized) journalism or reportage on the other (see Flis 2010: 33). In Adamic's case, his books are usually in the nonfiction realm (with the exception of the novels Grandsons: A Story of American Lives, 1935 and Cradle of Life: The Story of One Man's Beginnings, 1936).

4 Literary journalism is frequently discussed together with New Journalism, which is simply a narrower notion, applied to the type of journalistic writing that employed literary techniques and was produced especially in the U.S. in the 1960s and 1970s. 
and standards in a long evolution over several centuries - an evolution in which the most dramatic changes came in response to disruptive cultural forces such as revolution, economic depression, war, and liberation - and has its basis in the origins of nonfiction prose" (Sims 2007: 20). ${ }^{5}$ Apart from Tom Wolfe, the names that were mostly associated with literary journalism in the 1960s and 1970s were Truman Capote, Norman Mailer, Gay Talese, Jimmy Breslin, Dick Schaap, Terry Southern, Hunter S. Thompson, Gail Sheehy, George Plimpton, and Joan Didion. Joan Didion is still on the literary scene, and has managed to successfully integrate her writing into the writing world of a younger generation of literary journalists such as Michael Lewis, Lawrence Weschler, Eric Schlosser, Jon Krakauer, Ted Conover, Barbara Ehrenreich, Susan Orlean, Tracy Kidder, and Sara Davidson.

Literary journalists bring themselves into their narratives to a greater or lesser degree ${ }^{6}$ and expose human emotions, our everyday failings and exploits. Even though literary journalists usually prefer to focus on subject matter that otherwise tends to be pushed to the margins of society and avoided by the mainstream media, giving the voice to the voiceless and the invisible, it is still common to find familiar, even famous names in their texts. They always strive to draw a pluralistic landscape composed of various voices that stem from a broad and varied range of protagonists. Adamic, for example, wrote about well-known people from Yugoslavia, including Oton Župančič, Ivan Cankar, Nikola Tesla, Miroslav Krleža, Ivan Meštrovič, as well as numerous American writers and journalists (e.g. Sinclair Lewis, Edmund Wilson, H. L. Mencken, John Steinbeck), and naturally a lot of political figures, including Tito, King Alexander, Franklin D. Roosevelt, and Winston Churchill. Moreover, his books often included documentary material in the form of photographs (for instance The Native's Return, 1934; From Many Lands, 1940; My Native Land, 1943; and A Nation of Nations, 1945), ${ }^{7}$ which is a relatively common element in literary journalism and documentary prose.

Adamic's writing often reveals the author's immersion in the subject matter, structured narrative, the presence of the individual voice of the writer/journalist, the use of novelistic techniques (e.g. dramatization, dialogues, distinctive plot, and character formation), and, last but not least, an empathetic stance towards the characters of the narrative. Or, as Henry A. Christian writes in one of his essays on Adamic, referring predominantly to Adamic's longer narratives (specifically those that veer more clearly into a fictional direction, but nonetheless making a valid point that can be applied to Adamic's documentary texts): "His developing use of the fictional narrative

5 The terms nonfiction and documentary prose (or more specifically, "documentary novel") can be used as synonyms.

6 The technique of being a part of the narrative, of diving into one's transcribed reality is often termed "immersion" (see Sims 1984: 8-12; Flis 2011: 116).

7 A Nation of Nations is part of the tetralogy titled Nation of Nations; the first book is From Many Lands (1940), Two-Way Passage (1941) is the second, the third is titled What's Your Name? (1942), and the last is A Nation of Nations (1945). 
'I' in combination with an emphasis on personal, factual accounts of the American experience was leading to work which would eventually mark him as a prophet of what was called in the 1960s 'the New Journalism'"' (Christian 1977: 49). Like his journalistic successors (as well as some predecessors in the sphere of literary reportage) in the 1960s and afterwards, Adamic found himself saddled with the rules and formulas of conventional reportage that made it impossible for him to deal adequately with his subjects.

Like other literary journalists, Adamic revolted against rigid forms such as the "inverted pyramid" typical of conventional, factual journalism, where isolated facts are presented in declining order of importance. He looked for a "larger truth" than that provided by conventional reportage. It should be noted that Adamic sometimes crossed the line between fact and invention (usually for purposes of dramatization); he allowed himself freedom of imagination in reconstructing events, which is something a "proper" literary journalist would not be allowed to do (as they strive to achieve high standards of accuracy). In particular his book Dynamite (1931) is known to contain inaccuracies and sensationalism, traits that high-quality literary reportage would not display. Nevertheless, he usually managed to exquisitely capture the atmosphere and the nuances of the places and events he depicted. In his work My America (1938), Adamic says: "I believe that the drama of things is the truth of things [...] To write truthwardly, then, is to write dramatically" (Adamic 1938: xii).

As previously noted, the beginnings of literary journalism can be traced back to at least the late nineteenth century, if not further back into history (with Daniel Defoe's writing in the $18^{\text {th }}$ century), so at the time Adamic stepped more confidently onto his journalistic and literary path (at the beginning of the 1930s), there were writers present who, at least in part, had been following this tradition of writing for a while, namely Theodor Dreiser, John Dos Passos, Edmund Wilson, James Agee, George Orwell, and John Steinbeck. Edmund Wilson, who was a successful journalist, writer and critic, influenced Dreiser as well as Upton Sinclair, Sinclair Lewis and F. Scott Fitzgerald. All four of these writers impacted Adamic's writing to a certain degree. Moreover, Adamic occasionally uses irony or satire (this is particularly apparent in his articles in Harper's, The Nation, The Saturday Review of Literature and T\&T journal); this is a device that prevents him from becoming too sentimental, and it is an inheritance from the American essayist, scholar, cultural critic and editor of The American Mercury, H. L. Mencken. In his book Laughing in the Jungle, Adamic notes that in his "contemplation of the American scene, Mencken was for a good while the most important light" (Adamic 1932: 262). He goes on to say:

I read every work in the first number of Mercury and during the next two or three years delighted in the apparent success of the magazine [...] I delighted, too, in the effect that the success of the Mercury had upon the other so-called quality magazines; in all of them there began to appear better articles and short stories [...] I liked Mencken's gusto, his prose, and his lightning humor; his laughter - "the laughter of 
Hercules," as some one called it, which aimed to sweep from American intellectual life the unhealthy delusion of democracy, fake uplift, and other forms of "swinishness". (Ibid)

It is in turbulent times that journalism seems to thrive the most and is particularly motivated to delve into the very heart of human stories with authenticity and immediacy. The time of the Great Depression in the U.S. surely offered a fertile ground for bringing the reader into the essence of human suffering, and Adamic, like many other writers of the time, found it impossible not to address the issues of that devastating economic, social and political downturn. Sims points out that the first serious newspaper coverage of the Great Depression came sometime around the latter part of 1932. That was the time of "great erosion of confidence and trust among the middle class [...] the suicide rate rose, a million unemployed wandered the country, and thirty-eight states closed their banks" (Sims 2007: 134). These were the conditions in which a style of journalism appeared that "drew on such predecessors as the sociological style of the Muckrakers and anticipated many of the characteristics of the New Journalism of the 1960s" (ibid.).

As mentioned above, Adamic reacted to the struggles of the 1920s and 1930s in his book Dynamite: Story of Class Violence in America (1931). ${ }^{8}$ Adamic makes a clear connection between mass unemployment, organized labour, and organized crime. In the chapter "Labor and the Beginnings of 'Racketeering'", he writes:

It goes almost without saying the Capone gang will make use of the unions, perhaps in a political way, or perhaps to gain control of the contracting business in Chicago [...] I have little doubt that labor racketeering will increase [...] We need not be surprised when we realize how close the relationship is between organized labor and organized crime. Nor need we be shocked by the thought that organized labor was a vital factor in the early history of modern racketeering, that, indeed, organized labor, perhaps more than any other economic group, started the professional criminals whose names now shriek in the headlines of their amazing careers. (Adamic 1931: 118, 250)

The book certainly shows traces of literary journalism; many chapters are pieced together from his longer articles that were published in Harper's Magazine. They contain full-bodied descriptions of situations, dialogues and clearly-drawn protagonists, but unfortunately they lack factual accuracy, so by academic and (literary) journalistic standards the book falls short. One of the earliest reviews, written by American economist Edwin E. Witte in 1931 and published in Journal of Political Economy, suggests

8 Dynamite is in fact Adamic's second book. His first book was a short biography of an American poet Robinson Jeffers, whom Adamic greatly admired. His study was published in 1929 by the University of Washington Press. Prior to that, Adamic had translated Ivan Cankar's Yerney's Justice (Vanguard Press, 1926). 
that significant causes of violence (such as the spying and security guard systems of the private detective agencies) are treated inadequately in Adamic's book; moreover, Witte suggests that Adamic simply left out some of the major instances of violence that occurred within labour clashes. Indeed, Adamic makes no mention of the massacre that occurred in Herrin, Illinois in 1922 during a nationwide strike of the United Mineworkers of America, when more than 20 people were killed, for example. Thus the book cannot be treated as a reliable historical record, as it leans too much towards the sensational and rhetorical, yet it still manages to give the reader perceptive and sympathetic (towards the working classes, not the trade union leaders) insights into the trajectory of industrial relations and class struggles in the U.S.

In this work and the preceding articles, Adamic was mostly inspired and influenced by other American writers who, as early as 1929, exposed the reality of the Depression to the American public in the form of literary reportage in small-circulation political journals such as The Nation and The New Republic, but also in more widelyread magazines such as Harper's and The Atlantic (Flis 2011: 130). ${ }^{9}$ It is hard to ignore Adamic's pessimism in Dynamite, his not believing in workers' capacity to overcome "the conditions of their lives and the country's deeply ingrained individualism", as Jon Bekken notes in the Foreword to Dynamite (Adamic 2008: XII). Bekken goes on to explain that pessimism caused Adamic to leave the Socialist party in the 1920s (ibid.). This pessimism is in part reiterated in his memoir (again displaying traits of literarized reportage) Laughing in the Jungle: The Autobiography of an Immigrant in America (1932), which mainly deals with the author's reactions to his new living environment and the people in it, and where Adamic, in an unequivocal way, already introduces the topics of immigration and problematizes the notion of assimilation. Adamic was always looking for a story to tell, and found America to be an inexhaustible source of material for his journalistic and literary as well as his social and political agenda. In the postscript to Laughing in the Jungle, he recorded thoughts that sound incredibly relevant even today, and at the same time brilliantly reveal his personal and professional drives and ambitions:

[...] It may be that the tide of dissatisfaction with the more obvious characteristics of American life and with American values, so boldly glorified and personified by Herbert Hoover in 1928, is beginning to heave. It may be that we are in the midst of a revolution; that before many years this tide of dissatisfaction will seize the crazy overproductive and destructive forces now loose and uncontrolled in the jungle, and try to transform the jungle into a civilization [...] Meantime, personally, I still have no real complaint against America, the jungle. I have come here for excitement and adventure. (Adamic 1932: 335)

9 The list of contributors includes Edgar Lawrence Smith, Alice Hamilton and Sidney Hillman, to name a few. We should also note names such as John Dos Passos, Walker Evans and James Agee, as the leading chroniclers of the Depression era. 
Laughing in the Jungle is Adamic's attempt at creating a holistic diagnosis of life in the United States. Regardless of the fact that he is in favour of the spirit and the potential of his new homeland, he is also unequivocally critical. He saw the American interpretation of the notions of freedom and democracy as a convenient platform for brutal individualism and exclusionism, leading to social disarray and class violence. For Adamic, laughing as long as it is still possible to laugh is a means of survival, a therapeutic tool for dealing with a society with twisted ethical and social norms, a society which, by yearning for material power, dismisses its own spiritual and humanistic values. The book foreshadows the idea of cultural pluralism that Adamic fully developed during his years of editing the journal Common Ground.

The desire to uncover social injustices and to give voice to the voiceless and the unseen is a drive that has connected literary journalists through time and space. Meticulous research, the development of clearly recognizable personal style and voice, and first-person story-telling became more and more popular techniques in journalistic circles, and Adamic was no exception. However, he often mentioned Upton Sinclair's novel The Jungle (1906) as one of his primary influences. This is no real surprise, as Sinclair paved the way for research journalists as well as for more sensationalistic muckraking reporting trends. The book was in a sense Adamic's initial introduction to America. In Laughing in the Jungle, Adamic explains his reaction to Sinclair's book: "It was simply written, obvious in the extreme, and I understood nearly every word of it. I was young, just sixteen, and the book made a deep impression on me! So this was America! For a few days I felt a sharp hatred for the whole country" (Adamic 1932: 79).

Moreover, Adamic's long-lasting correspondence with Sinclair (between 1923 and 1946) had a crucial impact on his writing. As a deeply socially engaged writer, Adamic was politically quite active, and Sinclair didn't approve of this, stating that Adamic should decide whether he wanted to become a politician or a serious writer. The last piece of advice Sinclair gave Adamic concerned his manuscript Dinner at the White House (1946), which Sinclair carefully reviewed, suggesting some improvements and revisions. After that, their correspondence faded. Even though The Jungle made an impression on Adamic at first, he later noticed certain shortcomings in the book. In his article in the January 1927 issue of Halderman-Julius Quarterly, he praised Theodore Dreiser and noted that something was missing in The Jungle, whilst Dreiser was portrayed as a great writer and a true inspiration. ${ }^{10}$

In Rooting Multiculturalism (2003), Dan Shiffman explains that Adamic "read widely and deeply in American literature and history, both academic and populist works, but he lacked full awareness about his intellectual debts and, as a nonacademic, did not feel a particular responsibility to acknowledge them" (Shiffman 2003: 168). In Laughing in the Jungle, Adamic lists the authors he read with great interest: 
Sinclair Lewis, with Babbitt and Arrowsmith, helped me immensely to know America in a broad way. I continued to read Theodore Dreiser. An American Tragedy impressed me powerfully. I came upon Sherwood Anderson, Ben Hecht, James Stevens, Van Wyck Brooks, Ruth Suckow, Eugene O'Neill, Cabell, and others. Of the foreign writers, I read Anatole France, Joseph Conrad, D.H. Lawrence, Knut Hamsun, Thomas Mann, and Romain Rolland. (Adamic 1932: 264)

Still, as correctly viewed by Shiffman, Adamic's education in America "came primarily from his vast and varied contact with a dazzling range of Americans, including immigrants like himself who faced the difficulties of adapting to a new country" (Shiffman 2003: 168).

Adamic's writing stems from a tradition of authors who dealt with the gritty details of everyday life and used the documentary tone of narration as his primary means of revealing the absurdities and antagonisms of life in America and beyond. Shiffman notes that Adamic attempted to create a critical distance towards his chosen topics, but, unlike Mencken, for example, "could not sustain a life of ironic detachment" in his works (Shiffman 2003: 33). Subjectivity as such is not in itself a problematic issue when it comes to literary journalism; however, if it turns too moralistic or sentimental, it veers off from the platform that literary journalism supports. The paragraphs that follow will explore the characteristics of some of Adamic's works that align with literary journalism's endeavour to develop a "broader sensibility toward telling stories in journalism", as Norman Sims describes it (Sims 2007: 11).

\section{SOCIAL ENGAGEMENT AND MULTICULTURALISM IN ADAMIC'S LITERARIZED NARRATIVES}

It was apparent from the very beginning of Adamic's professional career that his vocation was not only that of a writer and a journalist, but also of an advocate of an ethical movement in the U.S., a social (and in part political) activist, and a literary and cultural critic. Throughout his writing career, Adamic was concerned with various aspects of social, ethnic, and racial discrimination in the U.S. and worldwide. The discrimination issues were particularly foregrounded in his articles in the journal Common Ground, which was the first American literary periodical devoted entirely to ethnic and intercultural matters. Adamic was very much involved with the complexities of the lives of (mostly European) immigrants in the U.S.

In his earlier analyses of the U.S. (immigrant) scene, he tended not to draw a clear line of demarcation between the concepts of cultural pluralism and assimilation, but later on, in his newsletters, his idea of "a nation of nations" resonated much more with the notion of ethnic pluralism. As John P. Enyeart notes in his article "Revolutionary Cultural Pluralism: The Political Odyssey of Louis Adamic, 1932-1951" (2015), in Common Ground Adamic became increasingly critical of assimilation and started to 
consistently promote pluralism. He believed that there had been too much melting away and shattering of the cultural values of various immigrant groups; he proposed an idea of an American cultural space which would have truly universal and pan-human traits. Or, as José-Antonio Orosco writes in his work Toppling the Melting Pot: Immigration and Multiculturalism in American Pragmatism: "Adamic is unique in that he challenges the melting pot ideal both from the perspective of an immigrant, as well as with accounts drawn from the perspectives of immigrants all across the country that describe how coercive the melting pot felt to newcomers" (Orosco 2016: 40).

The idea of a revolution in one form or another, the desire for a change of the political, legal and economic order in America, is an ongoing theme in Adamic's works. However, I will focus on those works where this particular subject is most distinctly elucidated, and at the same time presented in a form that goes beyond a conventional journalistic or historical narrative. Those books display Adamic's clear inclusion of his own perspective, the usage of a recognizable voice of the narrator, well-drawn characters and a well-defined composition, traits that literary journalists and documentary prose writers have employed throughout history.

Dynamite (1931) was, as Bekken points out, "the first popular general history of the American labor movement - a distinction it retained for more than twenty years, despite Adamic's frank admission that he had not set out to write a comprehensive history, but had rather focused on the question of the role violence had played in shaping the movement" (Adamic 2008: 1). Adamic opens this historical trajectory in the 1820s, when the labour movement was beginning to emerge, yet his book does not have a linear temporal structure, but is built around chapters that highlight particular issues or disputes that illustrate his broader argument (for example: "Criminals are Drawn into Class War"; "Violence in the West"; "Slaughter East and West"). The book is a vivid account of American class warfare, with Adamic being a first-hand observer, meeting with immigrant workers, the leaders of various labour movements, and academics focusing on the history of labour. He managed to provide valuable insights into the psychology of American workers as well as class violence. Still, as explained, the book was not researched well enough, and regardless of the strong impact the book made in the U.S., Adamic was also exposed to criticism from various labour unions, activists, and academics. ${ }^{11}$ With regard to the principles of literary reportage, Adamic uses excerpts from newspaper articles, conventions speeches, and directly quotes conversations with his interlocutors, giving his narratives a fairly solid structural framework, however, not yet as elaborate and as aestheticized as those in his later works. Still, Dynamite can be considered as the first legitimately successful attempt at a literarized narrative that strives, by applying the techniques of literarized reportage, to go beyond the mere listing of data.

11 For criticism on Adamic's book, see also Rudolph J. Vecoli's article "Dynamite: Adamic and Working Class America" (1981). 
In terms of questions regarding immigration and the multicultural dimension of the U.S., Dynamite doesn't yet pay a lot of attention to the implications of the predominantly immigrant nature of the American working class, or, as Bekken says, "to the important role immigrants' organizational networks played in sustaining a vibrant labor movement against overwhelming odds" (Adamic 2008: IX). This topic becomes more apparent in Adamic's work My America: 1928-1938 (1938), ${ }^{12}$ which connects revolutionary ideas with ideas of ethnic and racial differences in the U.S., thus introducing his yet-to-be-clearly-defined (but already recognizable) concept of multiculturalism. Shiffman describes My America as a combination of guarded autobiographical reflection, social commentary, portraiture, exhortation and investigative journalism (Shiffman 2003: 56). His investigative journalism undoubtedly takes on a literarized form, however, it is thematically very diverse, and sometimes it is hard for the reader to follow his narrative, due in part to the large number of names and references he uses. What Adamic shows us in My America are portraits of the labour leaders and literary figures who in his opinion impacted American society the most. He also focuses on "the U.S. government deportation polity, nativism, the social and psychological challenges experienced by second-generation immigrants, and the link between ethnicity and class consciousness" (Shiffman 2003: 56). Through the lens of Adamic's personal experiences in his adopted homeland, the book already portrays a pluralistic society, and that aspect sets forth the idea of multiculturalism. Adamic describes his intentions in this way:

Each of us living in the United States has his own America, that America is the aggregate, the sum-total of people, places, things, traditions, ideas, ideals, trends, institutions, conditions, and diverse other forces and factors in the country which, in one way or another, for this reason or that, have touched or influenced one's life and contributed to one's education - or confusion - as an American and as a person. (Adamic 1938: xi)

This opening paragraph reveals that Adamic, in the vein of a literary journalist, constructed "a multi-layered historical and psychological portrayal of the society in a specific period of time" (Žitnik Serafin 1993: 88). He wanted to give a diverse picture of a selected fragment in history and he did that by employing a multitude of voices and perspectives, which also aligns with his idea of cultural pluralism, expressed so well in his pieces in Harper's Monthly in the 1930s, as well as in the 1940s, predominantly in Common Ground.

This pluralistic and at the same time also fragmented reality that Adamic portrays through his literarized narration reached its most effective literary depiction when he wrote about America's ethnic diversity, which should "foster the growth

12 Adamic started working on My America at the same time as he was writing Dynamite, so some ideas were naturally transported from one book to another. 
of unsentimental empathy for the experience of others, to develop personal and national identity built upon a variety of critically examined cultural influences, and to create a more progressive and integrated society", as Shiffman puts it (Shiffman 2003: 153-154). As noted above, with his appeal for the recognition of historically oppressed racial or ethnic groups (while not demonizing the effects of the dominant culture), Adamic anticipates the contemporary ideas of multiculturalism. In some aspects, it also seems that Adamic's idea of America is close to John Dewey's notion of cultural pluralism as presented in his 1916 book Democracy and Education, as it rejects the melting pot's emphasis on assimilation. Adamic saw America as a hybrid culture with notable "cross-fertilization" among different ethnic, religious and immigrant groups. ${ }^{13}$ This notion is explained by Ksenija Šabec, who in her article "American Indigenous Peoples in Selected Works of Louis Adamic", ${ }^{14}$ still describes Adamic as a forerunner of the most influential contemporary multiculturalists, and states that:

[...] he demanded recognition for historically suppressed ethnic groups without demonizing the dominant culture, whilst, at the same time, expressing awareness of the versatility, ambiguities and absurdities of the American culture, which prevents the establishment of the complete balance between various ethnic and cultural 'inconsistencies' in America, and moreover, he understood the unity and versatility within the continuum of multiculturalism whose main origin and drive is its dialogical nature. (Šabec 2018: 155)

It should be stated that at the time My America was published, Adamic was already an established writer; in 1932 he received a Guggenheim fellowship for two of his previous works, Dynamite (1931), and Laughing in the Jungle (1932). In these two works, Adamic successfully internalized the rhetoric of literary, social, and political reportage, dramatized his compulsion to be involved in the subject matter, and consistently denied his readers a complacent, non-critical reading stance, all of which, as seen from his later works, proved to be life-long commitments in his writing (Flis 2011: 115). The award enabled him to travel to his homeland and produce one of his most significant books, The Native's Return (1934). ${ }^{15}$ This first-person narrative,

13 See Waks 2007: 27-37 and Orosco 2016.

14 Šabec 2018: 150-167.

15 The book became an almost immediate success, a bestseller in the U.S. and a Book-of-theMonth Club selection. This is how Adamic described the book's success in My America: "A year after my talk with Oton Zupanchich in Belgrade, The Native's Return was published in New York; and, as already suggested, the Book-of-the-Month Club distributed something like 50,000 copies of it the first month, and it was a so-called best-seller for nearly two years [...] I could not have written the book, had I not come to America and become an American writer. [...] No book that I, or anyone else, could possibly have turned out in Slovenia could have achieved such circulation. [...] Had I remained in Slovenia and become a Slovenian writer, I could not possibly have published a book that would have infuriated King Alexander, thrown the Belgrade Foreign Office into panic, and generally had an effect of a blow at tyranny." (Adamic 1938: 135) 
combining the features of an illustrated travelogue, a political and social commentary, and an ethnological study, reflects Adamic's strong penchant for literarization and offers a realistic and authentic description of the Yugoslavian social, political and cultural landscape. Generic hybridity is in fact a fairly common trait of literary journalistic pieces and to a large degree a constant in Adamic's writing. In The Native's Return he is very much focused on the stories of the common people he meets during his travels, aligning with the inclinations of literary journalism, but, of course, he also describes his meetings with the more publicly influential figures of the time (for example King Alexander I, whom he describes in detail in the chapter titled "I Met the King-Dictator"). This is how Adamic creates a literarized description of Ivan Meštrović, for example, mixing the present tense with the past tense, using an abundance of adjectives and a sentence structure one usually encounters in literature rather than in nonfiction:

When Stella and I first met him, Mestrovitch was nearly fifty - a stocky, short man with large, swarthy, but very attractive Slavic face. He is bald and has a soft black beard, beginning to be streaked with grey. He looks every inch an artist. Studying him, I thought he could be anything, do anything. At one moment his eyes are utterly weary, deep, tender, suffering; his full lips drooping, his soft voice tired. Then, suddenly, he says something or smiles, revealing his very white, strong teeth, and his whole personality lights up. At various times I saw in him a mystic, an adventurer, a Christ, a devil, a lover, a child, a seer, an ascetic, a Rabelaisian, a cheap politician and opportunist: a multitude of people, good and evil, but - basically, essentially - always an artist, a genius, vast, with unlimited possibilities [...] (Adamic 1934: 301, 302)

The themes of immigration, integration into a new living environment and the questions of assimilation and cultural pluralism are already charted in The Native's Return, however, not as clearly as in his later books. Moreover, The Native's Return is, understandably, more personal and at times almost sentimental, in comparison with Adamic's other books. This is especially true when the author is talking about his family, and especially his mother. This is how the writer describes seeing his mother for the first time after living in the U.S. for nineteen years (even though the passage focuses more on his mother's reactions, it is possible to detect Adamic's emotionality):

The sight of my mother, who waited for me (as I recalled in that instant) on the same spot in the courtyard of our home where I had said good-bye to her in 1913, gave me a sharp sting. She had aged and her body had shrunk; her hair was gray and thin, her eyes and cheeks were sunken, but her hug told me she was still hale and strong. She smiled a little and, holding my hands stiffly in front of hers, her body swayed a little, right and left, in sheer, unwordable happiness. (Adamic 1934: 20) 
Still, Adamic never lets himself get too carried away emotionally; he is aware of his simultaneous role as a cultural commentator, a philosopher, and a "contemporary humanist," as Boris Paternu describes him in his article "The Nascence of Louis Adamic's System of Values with Regard to America and Yugoslavia" (Paternu 1981: 85). Despite its focus being on Yugoslavia, The Native's Return also, in a comparative vein, depicts the American culture and presents it as ethnically versatile. It furthermore promotes the notions of human complexity and individuality, through which the book also sets the foundations for migration and ethnic studies.

Adamic's views on multiethnicity and multiculturality in the U.S. are broad and pluralistic. This is distinctly notable in his work A Nation of Nations (1945), where he structures his writing according to individual countries the groups of immigrants came from (e.g., "Americans from Italy"; "Americans from Spain and Mexico"; "Americans from Yugoslavia" and so forth). His analyses of individual groups of immigrants are preceded by a letter to his friend Merritt H. Perkins, in which he states that America should not be seen solely as an Anglo-Saxon country with a predominantly White Anglo-Saxon Protestant civilization, but rather a conglomerate of multiple immigrant identities. Once again, by using his unique, imaginative perception, he draws a vivid image of concrete reality. He writes:

The interplay, the diversity, is America; all that lacks is to transplant the fact from obscurity into American imagination. The rest will pretty much take care of itself, for the readjustment in thinking and feeling will reach into very nearly every phase of American activity. The reoriented cultural atmosphere of the United States will mean new, freer, broader ways of seeing and reacting, new and freer relationships. It will mean new integrations irrespective of background, integrations which let people remain themselves. It will bring into full view and play the healthy simultaneous tension and fusion of stubborn creative differences. (Adamic 1945: 13)

One more important point needs to be brought to light when it comes to A Nation of Nations, namely, Adamic's portrayal of both the progress and the exclusion of African Americans during World War II. He reports: "In 1943, a story current in the Negro world told of a wounded American Negro soldier in the jungle of a Pacific island who asked a comrade to paint these words on the cross marking his grave: HERE LIES A BLACK MAN WHO DIED FIGHTING THE YELLOW MAN FOR THE FREEDOM OF THE WHITE MAN" (Adamic 1945: 220).

Even though Adamic believed in the importance of nurturing pluralism when it came to American society and its social and cultural aspects, he still thought that pluralism needs to be viewed critically, as it does not always include all groups equally and it can, as Shiffman has it, "deny the complexity and multiple affiliations that constitute the lives of ethnic Americans" (Shiffman 2003: 95). 


\section{CONCLUSION}

Adamic's writing clearly exhibits a belief in a panhumanistic society that could develop in the United States and serve as an example for the rest of the world. He creates this vision through his intertwining of a multitude of views that range from those of migrant workers to leading politicians. Such a hybridity of sentiments speaks in favour of his unique humanistic stance that occasionally slips into idealism, but nonetheless provokes ideas that we can still benefit from today. Adamic was ahead of his time when it comes to notions of multiculturalism and energized civic action, and he used the genre of literary reportage (mixed with other genres) to put forward his ideas in such way that a wide-ranging audience could relate to them. He demanded an engaged reader and never worked against the authenticity of his narratives, thus properly aligning his work and mission with that of his most successful contemporaries in the sphere of journalism and literature. When reading Adamic's texts, Mark Kramer's words come to mind as well:

Journalism as a civic mission is about an address to citizens on bureaucratic forms. But beyond that, readers are people, and there's a world of real life people beyond newspapers. Reporters of narrative may now include the style of a subject, the flavor, motivation, longings, angers, loyalties, irrationalities. That's when you're in a position to do what the gods do, to breathe life into the clay citizen. Give us the gift an artist does of making people come alive. That's excellence. (Ludtke 2002: 8)

Adamic's legacy is as relevant and as convincing today as it was in his time, and it is no coincidence that his books are now (once again) being included in academic programmes in ethnic and migration studies, as well as studies of literary journalism and documentary narratives in a broader sense.

\section{REFERENCES}

Adamic, Louis (1932). Laughing in the Jungle: The Autobiography of an Immigrant in America. New York: Harper \& Brothers.

Adamic, Louis (1934). The Native's Return: An American Immigrant Visits Yugoslavia and Discovers his Old Country. London: Victor Gollancz LTD.

Adamic, Louis (1938). My America (1928-1938). London: Hamish Hamilton.

Adamic, Louis (1945). A Nation of Nations. New York: Harper \& Brothers.

Adamic, Louis (2008). Dynamite: A Story of Class Violence in America. Edinburgh, Oakland: AK Press.

Christian, Henry A. (1977). From Many Lands: Ethnic Literature Then ... and Now? Modern Language Studies 8/1, 48-56. 
Denning, Michael (1996). The Cultural Front: The Laboring of American Culture in the Twentieth Century. London, New York: Verso.

Dewy, John (1916). Democracy and Education, https://www.gutenberg.org/ files/852/852-h/852-h.htm (15. 2. 2019).

Enyeart, John P. (2015). Revolutionizing Cultural Pluralism: The Political Odyssey of Louis Adamic, 1932-1951. Journal of American Ethnic History 34/3, 58-90.

Flis, Leonora (2010). Factual Fictions: Narrative Truth and the Contemporary American Documentary Novel. Newcastle upon Tyne: Cambridge Scholars.

Flis, Leonora (2011). Louis Adamic - Slovene-American Literary Journalism Avant la Lettre. Slovene Studies 33/2, 115-132.

Ludtke, Melissa (ed.) (2002). Nieman Reports: The Nieman Foundation for Journalism at Harvard University 56/1.

Meyer, Gerald (2008). The Cultural Pluralist Response to Americanization: Horace Kallen, Randolph Bourne, Louis Adamic, and Leonard Covello. Socialism \& Democracy 22/3, 19-51.

Orosco, José-Antonio (2016). Toppling the Melting Pot: Immigration and Multiculturalism in American Pragmatism. Indiana: Indiana University Press.

Paternu, Boris (1981). The Nascence of Louis Adamic's System of Values with Regard to America and Yugoslavia. Louis Adamic: Symposium: 16.-18. September 1981 (ed. Janez Stanonik). Ljubljana: Univerzitetna tiskarna, 85-100.

Pells, Richard H. (1998). Radical Visions and American Dreams: Culture and Social Thought in the Depression Years. Urbana, Chicago: University of Illinois Press.

Petrič, Jerneja (1981). Svetovi Louisa Adamiča. Ljubljana: Cankarjeva založba.

Shiffman, Dan (2003). Rooting Multiculturalism. London: Associated University Press.

Sims, Norman (1984). The Literary Journalists. New York: Ballantine.

Sims, Norman (2007). True Stories: A Century of Literary Journalism. Evanston: Northwestern University Press.

Šabec, Ksenija (2018). Ameriški staroselci v izbranih delih Louisa Adamiča: Strpnost ni dovolj (prispevki konference Iz mnogih dežel: Ob 120. obletnici rojstva Louisa Adamiča). Borec LXX/751-753, 150-167.

Vecoli, Rudolph J. (1981). Dynamite: Adamic and Working Class America. Louis Adamic: Symposium: 16.-18. September 1981 (ed. Janez Stanonik). Ljubljana: Univerzitetna tiskarna, 155-166.

Žitnik Serafin, Janja (1993). Pero in politika: Zadnja leta Louisa Adamiča. Ljubljana: Slovenska matica.

Waks, Leonard J. (2007). Rereading Democracy and Education Today: John Dewey on Globalization, Multiculturalism, and Democratic Education. Education and Culture 23/1, 27-37.

Witte, Edwin E. (1931). Reviewed Work: Dynamite: The Story of Class Violence sin America by Louis Adamic. Journal of Political Economy 39/6, 826-828. 


\section{POVZETEK}

\section{DRUŽBENI ANGAŽMA IN MULTIKULTURALIZEM V LITERARNEM ŽURNALIZMU IN DOKUMENTARNI PROZI LOUISA ADAMIČA Leonora FLIS}

Članek se osredotoča na tiste zapise Louisa Adamiča, ki sodijo v kategorijo literariziranih reportaž, v daljših knjižnih zapisih pa prehajajo tudi v hibridne pripovedne tvorbe in združujejo elemente socialne in politične reportaže, avtobiografije, biografije, potopisa, etnografskih, antropoloških in etničnih študij. Prispevek ponudi analizo izbranih Adamičevih del (izpostavljene so knjige Dinamit, Smeh v džungli, Moja Amerika, Vrnitev $v$ rodni kraj in Narod narodov), pred tem pa razloži tudi zgodovinski razvoj in poglavitne lastnosti literarnega žurnalizma in dokumentarne proze ter prikaže, kako se $v$ domeno tega žanra umešča Adamič. Adamič se lahko brez zadržkov postavi ob bok osrednjim predstavnikom literarne reportaže in dokumentarne proze, tako svojim sodobnikom, kot so Edmund Wilson, James Agee, Martha Gellhorn in H. L. Mencken, kot tudi literarnim žurnalistom šestdesetih in sedemdesetih let 20. stoletja, ko se je ta žanr v ZDA še zlasti močno definiral in razširil (tu lahko navedemo imena, kot so Tom Wolfe, Truman Capote, Norman Mailer, Gay Talese, George Plimpton in Joan Didion). Članek ne poudari le Adamičeve vloge pisatelja in kronista svoje dobe, temveč tudi njegovo socialno agendo in aktivizem, ki sta izvirala iz želje po opolnomočenju tako delavskega razreda kot tudi priseljencev v ZDA, ki jim je Adamič v svojih zapisih namenil veliko pozornosti (tudi s prispevki v reviji Common Ground, ki jo je urejal v štiridesetih letih). Izpostavljena dela tako Adamiča ne predstavijo zgolj kot literarnega žurnalista z izbranim občutkom za pripovedno strukturo in narativne postopke, ki jih uporabljajo tudi beletristična dela, temveč, skozi njegovo kompleksno razumevanje tako socialne problematike kot etnične identitete, tudi kot predhodnika sodobnih idej multikulturalizma ter etničnih in migracijskih študij. 